SALATA OKSANA,

Borys Grinchenko Kyiv University (Ukraine),

e-mail: o.salata@kubg.edu.ua,ORCID0000-0003-2498-1483

\title{
THE IMAGE OF THE CITY EMBODIED IN ARCHITECTURE RATIONALISTIC MODERN STYLE OF ALEXANDER VERBITSKY
}

\begin{abstract}
An image of architectural forms created in the urban environment always attracted interest. Researching of city space, in particular an architectural image of the city and its influence on consciousness of inhabitants, is considered to be important in this context. In formation of new images of city space modern architects conduct search of forms which would be connected with national tradition and, at the same time, met production requirements of modern town planning. Research objective - to reveal features of a rationalistic modernist style in Ukraine on the example of works of the famous Ukrainian architect Alexander Matveevich Verbitsky. Research problems: 1) to track features of the Ukrainian rationalistic modernist style in the architectural forms created by A. M. Verbitsky; 2) to render the general signs of style of national architecture on examples of the buildings built in Kyiv; 3 ) to determine the value of inheritance of a rationalistic modernist style in Kyiv, ways of its preservation as component of the all-European inheritance.
\end{abstract}

Keywords: city; architecture; rationalist modernist; Alexander Verbitsky.

Introduction. Architectural constructions of Kyiv became material of a research: the main facade of the Kyiv national bank, a frame of the assembly hall of the Kyiv polytechnical institute, multystoried houses in Kyiv, locomotive depot of Darnitsa, the Kyiv railway station. On the example of architecture constructions which instructions of the beginning of the $20^{\text {th }}$ century it became possible to track a work of the architect with elements of national traditional style and thereof to determine their value for cultural inheritance of Ukraine.

Method's groundwork of the work is based on the research methods used by a modern science. The article was done on the principles of historicism, objectivity and scientific ability. In the work the state of scientific development of problem is analyzed in domestic and foreign historiography. Basic conceptual approaches used to study the problem have been defined. Presented research work has scientific novelty in the context of the foreign historiography. The image of the city is embodied even in works of Ancient Greek philosophers and in treatises which resemble from the Ancient East. In particular much attention was paid by idea of the ideal city (an arrangement of settlements, distribution of inhabitants behind the statuses, divisions of labor according to the statuses and opportunities), and also analyzed forms of government (existing and probable) in policies (city-states). East treatises were a bigger measure to this devoted architectural direction therefore as have to be organized and how the cities have to be under construction.

The subject of creation of an image city environments was investigated by both foreign, and domestic scientists. In particular it is the researching devoted to art figurativeness and symbolization in architecture and presented in fundamental works of L. Alberte, K. Ledu, E. Bulle, K. Lyncha, R. Ventura, Ch. Jenks, K. Tange, C. Alexandera, etc. A question of art figurativeness in architectural and townplanning design was considered in theoretical works of Bulakh I. V. where he considers experience of formation in the urbanistic environment of the symbols and images inherent only in the concrete city (Булах, 2014: 577-583).

$\mathrm{O}$. Gutnov and V. Glazychev in the general work open an image of the city as a product of action of consciousness of its inhabitants (Гутнов, Глазычев, 1990: 352). Brightly Chepelik V. V. presented in the works national traditions in Ukrainian architectural moderny. He and his colleagues considered that traditions help to create unique architectural style city environments (Чепелик, 2000b: 14-16).

Research objective - to reveal features of a rationalistic modernist style in Ukraine on the example of works of the famous Ukrainian architect Alexander Matveevich Verbitsky.

Research problems: 1) to track features of the Ukrainian rationalistic modernist style in the architectural forms created by A. M. Verbitsky; 2) to render the general signs of style of national architecture on examples of the buildings built in Kyiv; 3) to determine the value of inheritance of a rationalistic modernist style in Kyiv, ways of its preservation as component of the all-European inheritance.

Presentation of the main material of the study. In a number of a romantic modernist style of the different countries the Ukrainian architectural modernist style holds a specific place. Unlike a "northern" modernist style (national romanticism) which has a certain similarity within the Scandinavian and Baltic countries (St. Petersburg and in other cities near St. Petersburg) and gained a certain international character, the Ukrainian modernist style kept originality inherent in it and originality and did not extend from the territory of Ukraine. Comparing objects of the Ukrainian architectural modernist style (a national and romantic modernist style of Ukraine) to objects of a national 
and romantic modernist style of the countries of Scandinavia or the Baltic countries, it is possible to see absolutely different composition methods and front decisions despite the fact that some elements, such as trapeze cuts, equally widespread in "northern" moderny, and in the Ukrainian architectural modernist style. In "northern" a modernist style they have an origin from trapeze forms of dormer-windows, in the Ukrainian architectural modernist style - from trapeze jambs of the ancient wooden churches decorated to woodcarvings. The character of the Ukrainian architectural modernist style is absolutely another in comparison with objects of the Scandinavian "northern" modernist style. There is the main difference between these styles. It is that in Ukrainian modern inherited and modernized forms of wooden architecture, and in Scandinavian "northern" a modernist style - forms in a stone. Therefore the Ukrainian architectural modernist style seems to be easier, distinguished, expressly developed up vertical composite decisions. The "northern" modernist style is considered to be more "brought closer to the earth" and similar to forms of natural rocks (Слєпцов, Івашко, 2013: 11-12).

The Ukrainian modernist style was created on the basis of features of national culture, in particular successfully united domestic national traditions, characteristic proportions of the people's rural house and wooden church architecture with modern understanding of convenience. In a decor motives of the Ukrainian embroidery, wooden carvings were widely applied. Feature of the Ukrainian modernist style was the fact that at the beginning of 20 century two main directions were created: national and rationalistic modernist style. Sometimes it is called "a constructive modernist style", "a decorative modernist style", "a romantic modernist style". The Ukrainian modernist style with lines of national traditions was allocated with a pronounced inclination to romanticism, florid picturesqueness, considerable decorative effect.

In Ukraine at the beginning of the XX century so-called rationalistic modernist style seemed to be distributed. It is presented mainly on Kyivshchyna, the Kharkiv region and Poltavshchyna. The rationalistic modernist style turned out to be a simple construction into distinguished and functional. In architecture lines of this style were most brightly shown in works of the famous Ukrainian architect Alexander Matveevich Verbitsky. These constructions inherent logical regularity of architectural thinking, functional validity of an object, judgment of opportunities of new designs, floridity of a decor.

In style of a rationalistic modern during the prerevolutionary period hospitals, schools, stations etc. were built there. The house of a zemstvo in Poltava built $1905-1909$ behind the project of the architect V. Krichevsky - the mentor Alexander Matveevich Verbitsky who absorbed romanticism of style and became the famous architect (Чепелик, 2000a: 120) was the best construction which presented this style.

In the first decade of the XX century behind Alexander Matveevich's projects in Kiev, Kharkiv, Cherkasy and many other cities of Ukraine multystoried houses, hospitals, educational institutions came down. His architectural works can be referred to the best properties of the Ukrainian Soviet architecture. Right after the end of training in 1898, at the St. Petersburg institute Alexander Verbitsky in team of architects of professor I. S. Kitner took part in construction of a complex of Polytechnical institute, then V. G. Nikolaev worked at a construction of the Kiev opera theater as the foreman and the assistant to the foreman academician (Чепелик, 2000b: 74).

In 1901 A. M. Verbitsky developed the project of the main facade of the Kiev national bank (to a superstructure). This project was embodied at life by the architect O. V. Kobelev who had directed construction. Architectural shapes of a facade of bank were executed in early Renesans's style with some elements of Gothic and Romance architecture. In surprising design the architect connected the North Italian gothic style and the early Florentine Renaissance. Decorating of bank - a merit of the Italian master Elio Sal, author of the well-known fantastic beings on the House with chimeras. From the outside the building of National bank is a romantic image and inside - the exact mechanism designed for effective work of the main bank of the country. Architectural refinement and technical perfection of the building emphasize a special role of the central bank designed to direct a financial system of the state. Purpose of the building is emphasized not only by a practical functional part and symbolism of its frame.

The front part of the building of bank was issued by the architect Alexander Verbitsky. On a facade he placed the coats of arms of three provinces which were served at that time by bank, - Kiev, Podolsk and Volynsk. Nearby - four coat of arms of different fields of activity which needed by the bank credit:

- Mercury staff a caduceus symbolizes trade;

- a cogwheel, compasses and T-squares (engineering symbols) - the industry;

- a chain and sheaves of cones - agriculture;

- also covered an anchor, a wheel - transport.

From a building facade griffins fixedly monitor the movement on Institutskaya Street. Behind antique mythology griffins protected gold mines of Scythians.

The magnificent Operational hall of bank was decorated with sculptures of antique gods.

- Hermes helps with receiving profit and trade;

- Demetra protects agriculture and fertility;

- Athena the Pallada allocates with wisdom;

- Hephaestus helps with a routine to perfect skill and professionalism (Історія центрального банку України $\left.{ }^{1}\right)$.

Later Alexander Matveevich worked in Management of the Southwest railroad in Kyiv. He developed the outline sketch of the Kyiv station and in 1928-1932. Its construction was carried out. It was reduced from reinforced concrete designs in style of constructivism with baroque elements in the central part to a lobby, in comparison with thirty seven meter dominant where a wing seems imperceptible. Accent in a look was broken line of a pediment, five-pointed side walls, and huge half elipse windows of an axis of symmetry which harmoniously connected with socle arches and rectangles of windows side parts were taken up.

The central place in symmetric composition was taken by a departure lobby. This biggest room is 37 meters height with a huge window cut. The giant sizes window with clock has the form close to parabola, but the architect drew his outlines, without using laws of mathematics, "by hand". The form of a window cut which something reminds baroque pediments of the Ukrainian architecture of XVII to XVIII centuries was result of long-term studying of architecture of Ukraine, but there is no hint for antiquity

\footnotetext{
${ }^{1}$ Історія центрального банку України. URL: https://bank.gov.ua/ control/uk/publish/article?art id=36110
} 
also. A. M. Verbitsky creatively comprehended architecture of the past and, transforming its forms through the consciousness, found simpler, laconic and expressive architectural decisions.

Design and construction of the Kyiv railway station most fully disclosed Alexander Matveevich's talent, his creative person found the manifestation here. Restraint of an art frame, laconicism, refined proportions, simplicity and clarity of a plan, diligence in development of plans in combination with fruitful search of national forms in modern architecture - all this found bright display here. Throughout 1930 years Verbitsky projected and built a large number of different constructions behind the projects. There are a viaduct at the station Kovel, the same station, Globi and Balta stations, commodity offices, numerous locomotive depots, the plants, educational institutions, hospitals, houses. Behind O. G. Verbitsky's projects reduce constructions and outside Ukraine - in Moscow, Batumi, Chisinau, Gomel.

Verbitsky also developed projects of industrial constructions. It is necessary to remember locomotive depot in the Darnytsia district of Kyiv. It is also reduced in style of a rationalistic modernist style with baroque elements refined eaves, pilasters, arches over windows and gate. The author placed emphasis on the central part of the room where huge half elipse windows had been taken up symmetrized to socle arches and side parts (Чепелик, 2000a: 200). For 1904-1913 Alexander Verbitsky developed projects on which it was built multystoried houses in Kyiv on Engels street, at the corner of Streletskaya and Reytarskaya's streets. At design of premises the architect with special attention developed not only planning of apartments but also attached great value to an external frame of facades. In an external frame of a construction the architect applied facing ceramics, and also a ceramic panel on mythological subject over a bay window. The panel is executed by the architect in a co-authorship with the artist O. Kozlov. Also famous artist Vrubel worked in creation of ceramic panel and a glazed sculpture. The architectural concept of a facade of a house at the corner of Reytarskaya and Streletskaya's streets attracts not only with plasticity of facades with convenient bay windows of a different form, and a peculiar processing of facades. There are brick under jointing of seams, modelled ornaments, wonderful painted details of balcony protections. Facade proportions of windows of a different form have uncommon value.

A. Verbitsky embodied characteristics of the Ukrainian architectural style of the beginning of the XX century. In the architectural projects it was often shown the design of roofs which had mainly high four level forms and reminded roofs of people's houses. Tower shaped performances on roofs or the last floors also quite often crowned pyramidal roofs, sometimes from pear-shaped domes, even with poppy-heads. In some projects the architect applied trapeze forms pediments or triangular nippers on a roofs. In case of application such elements the house got a silhouette, active and romantic character, which distinguished them from other constructions. Prototypes of classic people's house, belltower or wooden church received sometimes mechanical reproduction or updating, processing and development of architectural forms, but always so that communication with the primary source was not lost, thanks to it forms which became symbolical signs emphasized belongings to the Ukrainian architectural style.

When he had projected constructions from a brick, walls had natural color of ceramics. Their compositions prevailed piers over openings. The last had the rectangular or rounded-off or cut forms. Trapezoid window and door openings gained value of the most characteristic sign manifestations of the considered style. It allowed it to develop a large number of versions of portals in which this form was applied in columned patios, loggias, niches, bay windows, roofs and pediments which extremely increased architectural expressiveness, approved a high end development of tradition.

Decorative adornments on facades often had an appearance of ceramic inserts with the color ornaments, generalized, mainly geometrical or more naturalistic behind character, constructed at combination of colors and birds, heraldry elements which in some cases developed into difficult picturesque panels. Among the decorative forms of application were sockets, triangular inserts, friezes, color strips, impregnations in the form of separate tiles which considerably recovered the wall plane. Application of picturesque increased expressiveness of architecture, provided to it original lines, but was beaten off by especially national traditions which were created in the course of performance of house lists, embroideries or sewing. To keep integrity of style in a front part and an interior Verbitsky suggested to establish doors and windows, with carvings.

\section{Conclusions}

So, it is possible to claim that at the beginning of the $X X$ century the style direction in the Ukrainian architecture - a rationalistic modernist style was created. Its development happened in the general course of development of the ideas which were then delighted all world architecture, from eclecticism, moderny, neoclassicism to rationalism. Feature of this style is that it relies on the rich traditions of national architecture which are saved up by ages. This inheritance needs to be reinterpreted. That's no doubt it is important this style should be given a new further development but already in the conditions of modern requirements and realities.

Thus the value of inheritance of a rationalistic modernist style in Kyiv brought by Alexander Matveevich Verbitsky is incontestable. Ways of its preservation as component of the all-European inheritance demand that new researches should be not only in architecture as an art form but also in the reproduction of necessary monuments. The Ukrainian architects have to carry out searches of styles which would give the chance to make domestic architecture attractive, close to national traditions and, at the same time, modern.

\section{REFERENCES}

Bulakh, I. and Cherkes, B. S. (Ed.) and Petryshyn, G. P. (Ed.). 2014. In Theoretical experience of symbolization in creative urbanism. Lviv: Publishing House of Lviv Polytechnic: 577-583 (ukr).

Gutnov, A.E. and Glazychev, V.L. 1990. The World of Architecture: The Face of the City. Moscow: Molodaja Gvardiya, 352 p. (rus).

Sliptsov, O. S. and Ivashko, Yu. V. 2013. Ukrainian architectural modernism as evidence of the identity of the people. Modern Problems of Architecture and Urban Development: Sci. Tech. collection. Issue 32. Kyiv: KNUBA: 11-12 (ukr).

Chepelyk, V.V. 2000a. Ukrainian Architectural Modern. Kyiv: KNUBA, pp. 120 (ukr).

Chepelyk, V.V. 2000b. Formation of the Ukrainian architectural modernism of the early twentieth century. in the context of 
international creative ties. In the book: Ukrainian Art and Architecture of the End of the XIXth Century of the XX Century. National Academy of Sciences Institute of Art Studies, Folklore Studies and Ethnology. MT Rilsky. Kyiv: Naukova Dumka. P. 74 (ukr).

Chepelyk, V.V. 1994. Ukrainian Art Nouveau in Kharkiv (Profitable Dwelling Houses). Starozhytnosti. No. 5-6 (64-65): 1416 (ukr).

\section{LIST OF REFERENCE LINKS}

Булах I. В Теоретичний досвід символізації у креативному урбанізмі: монографія. За заг. ред. Б. С. Черкеса та Г. П. Петришин. Львів: Видавництво Львівської політехніки, 2014. С. 577-583.

Гутнов А. Э. Глазычев В. Л.Мир архитектуры: Лицо города. Москва : Молодая гвардия, 1990. 352 с.
Слєпцов О. С., Івашко Ю. В. Український архітектурний модерн як свідчення самобутності народу. Сучасні проблеми архітектури та містобудування: наук.-техн. збірник. Київ: КНУБА, 2013. Вип. 32. С. 11-12.

Чепелик В. В. Український архітектурний модерн. Київ: КНУБА, 2000а. С. 120

Чепелик В. В. Формування українського архітектурного модерну початку XX ст. у контексті інтернаціональних творчих зв'язків. В кн.: Українське мистецтво та архітектура кінця XIX початку $X X \mathrm{~cm}$. НАНУ. Інститут мистецтвознавства, фольклористики та етнології ім. М.Т.Рильского. Київ: Наук. думка, 2000b. С. 74.

Чепелик В. В. Український модерн у Харкові (Прибуткові житлові будинки). Старожитності. 1994. № 5-6 (6465). С. $14-16$.

\section{Салата Оксана,}

Київський університет імені Бориса Грінченка (Украӥна), e-mail: o.salata@kubg.edu.ua, ORCID 0000-0003-2498-1483

\section{ОБРАЗ МІСТА В РАЦІОНАЛІСТИЧНОМУ МОДЕРНІ АРХІТЕКТУРИ О. М. ВЕРБИЦЬКОГО}

У статті досліджено та розкрито особливості раціоналістичного модерну в Україні на прикладі творів відомого українського архітектора Олександра Матвійовича Вербицького (1875-1958). Методологія дослідження включає низку наукових методів і підходів, серед яких аналіз, синтез, порівняльний та культурологічний, які дали змогу проаналізувати особливості українського раціоналістичного модерну в архітектурних формах, створених О.М. Вербицьким, як важливого етапу в українській архітектурі та українській культурі. Наукова новизна полягає у спробі автора виявити загальні ознаки стилю народної архітектури на прикладах будівель, споруджених у Києві, та визначити цінність спадщини раціоналістичного модерну в Києві, шляхи його збереження як складової частини загальноєвропейської спадщини. Показано, що оригінальність Київської школи модерну полягає в широкому використанні геометричних форм при одночасній стриманості декоративних традицій. 3 цієї позиції проаналізовано найбільш відомі архітектурні споруди авторства О.М. Вербицького будинок залізничного вокзалу та передвокзальної площі, паровозного депо станції Дарниця, багатоповерхові житлові будинки у Києві по вул. Енгельса, на розі вулиць Стрілецької та Рейтарської. Найхарактернішою ознакою архітектурного стилю Вербицького, є, на думку автора, акцент на проектуванні дахів, які були переважно високої чотирисхилої форми і нагадували обриси дахів народних хат. У деяких проектах архітектора використано трапеційну форму фронтонів або ж трикутні щипці біля коньків даху, що надавало силуетам будівель активного і романтичного характеру, підкреслювало зв'язок 3 класичними спорудами народної дерев'яної архітектури та українською традицією будування.

Ключові слова: архітектура; архітектурні стилі; раціоналістичний модерн; образ міста; культурна спадщина; пам'ятки архітектури.

(C) Salata Oksana

Надійшла до редакції: 02.10.2018

Прийнята до друку: 17.12.2018 